\title{
Surviving COVID-19 Pneumonia At Home: COVID Case \#1906
}

\author{
Dear Editor,
}

I was exposed to a COVID-19 positive cardiologist last March 1. I had ENT clinics until March 11, treating mostly patients with complaints of cough and fever (sinusitis and bronchitis). I felt that my facial mask, hooded magnifier lens, and gloves gave me enough protection. I was wrong. They were not sufficient. I had a temperature of $38^{\circ} \mathrm{C}$ on March 13 and went home immediately to self-isolate.

By March 15, I was coughing unremittingly and persistently as if a feather was stuck in my throat. I had no phlegm. I had no running nose, nor respiratory difficulty. But my rib muscles ached continuously - an intense, miserable pain not relieved by any position. I felt a severe point tenderness over both lower back ribs that even soft pillows could not diminish. I lacked sleep. I felt weaker as days went by. My taste was flat as I swallowed soups and arroz caldo but I still had my sense of smell.

On March 16, I took Clarithromycin $500 \mathrm{mg}$ and N-Acetylcysteine $600 \mathrm{mg}$, both twice daily to treat what I diagnosed as acute pharyngitis. Two more days of severe coughing, fever and sore throat made me worry about COVID-19. How come I was not getting better? In fact, I was getting BITTER over this uncertainty of COVID-19 and the treatment I had prescribed myself. I had been religiously taking probiotics to imbue me with immunity for infections like these. ${ }^{1}$ I believed that lactobacillus acidophilus, the friendly gut bacteria, stimulates the Gut Associated Lymphoid Tissue (GALT) to produce antibodies against virus and bacteria shedding into small intestines and against bacteria abnormally multiplying in the large intestine. ${ }^{2}$

I was assured by the research of Russian Dr. Elie Metchnikoff on the potent lactobacillus in yogurt (which comprised almost $50 \%$ of the Bulgarian diet and made them strong and healthy). Dr. Metchnikoff (who had won the 1908 Nobel Prize in Physiology and Medicine) honored Bulgaria by naming his friendly bacteria lactobacillus bulgaricus. ${ }^{3,4} \mathrm{Dr}$. Metchnikoff was later honored as the "father of natural immunity."

Then came the Spanish flu of 1918-1919 that killed more than 2.5 million Europeans, mostly Italians and British. ${ }^{6}$ Yet the number of those killed in Bulgaria was as close to that in Switzerland, which was the lowest. Now, the COVID-19 pandemic marched into 2020 killing 4,633 patients out of 82,918 COVID+ in Wuhan, China; 31,855 out of 219,183 COVID+ in Great Britain; 30,560 out of 219,070 COVID+ in Italy; and 80,787 out of $1,367,638$ COVID+ in the USA. Ninety-one died of COVID out of 1,965 positive for COVID-19 in Bulgaria. ${ }^{7}$

I was confident that the lactobacillus acidophilus 20 billion Colony Forming Units (CFU) were stimulating production of the $\lg G$ and $\lg M$ (from GALT which produces $70 \%$ of the body's immune globulins) needed to neutralize viruses or bacteria. ${ }^{8}$ The acidophilus produces Vitamin B specially Vit B129 which I believe made for my stronger body. I had prepared myself as I prepared my patients for the flu by consuming Vit $\mathrm{C}$ and Zinc. Zinc stimulates the thymus to increase immune responses to viruses. ${ }^{10,11}$ I was fortified with 2 Colostrum pills daily, preformed sources of $\lg G$ and $\lg A .{ }^{12}$

I followed my regimen for acute rhinitis (though there was no nasal obstruction) which meant doing nasal SALINE washing or sprays thrice a day. I knew that the flu virus (or even the SARS-COV2) hides EARLY in the nose and sinuses and is able to produce toxins which inflame the whole body. Worse for SARS-COV2 because these drop into the tonsils and into the lungs. The nasal sprays were meant to reduce the virus numbers (viral load) in the nose and sinuses so there were less shedding. Saline washes decongest the nose to improve breathing. The 60 seconds antiseptic mouthwash followed a regimen of brushing the teeth then the palate and the tonsils and to the base of the tongue. This was to extinguish any virus lurking to go down into the lungs or GIT. This regimen was routine at $3 x$ a day.

The fever dropped slowly. Coughing diminished though the muscles constantly ached after 3 days of Clarithromycin. I was determined to have the COVID tests and a high resolution CT scan of the chest. On March 20 at the hospital ER, I explained I was a patient requesting a CBC, a COVID test, and a chest CT scan and that I will wait for my turn since the ER was full (took me 3 hours). After the interview with the ER physician, I was led to a seat one meter apart from others. Elderly patients with cough all quizzically looked at me in my white doctor's gown wondering if I was sick. I changed to the gown, mask, and gloves I was provided with when the nurse escorted me to cubicle one. First came the CBC. Next were Rt-PCR swabs of the nose and nasopharynx and of the throat. Finally after the staff sterilized the CT scan room, my scan was completed in a few minutes. The chest scan showed ground glass appearance consistent with Bilateral Basal Pneumonia. I was told that the PCR results would be ready within 7 days.

I was advised urgently by my classmate, a pulmonary specialist from another hospital, for admission for oxygen inhalation and treatment. She went out of her way to look for a pulmonologist but none was available due to quarantine. She looked for an Infectious Disease Specialist who was now in isolation. I requested her that since I was not in respiratory distress and because of my weakened state, I was worried about getting a hospital acquired infection and that I be committed to strict home isolation with treatment prescribed by her. She reluctantly acceded with the admonition that I proceed immediately back to hospital if respiratory difficulties occur. I started the Oseltamivir (Tamiflu) at $2 x$ a day for 5 days and Azithromycin once daily for 7 days plus a mucolytic $\mathrm{N}$ - Acetylcysteine $600 \mathrm{mg} 2 \mathrm{x}$ a day.

There was another dimension beyond my physical stress. I was in MENTAL stress, the pervasive fear of not surviving this that engulfed me. Knowing my close colleagues died from COVID-19 pneumonia after a short battle in ICU with intubation, I realized THIS certainty of 


\section{LETTERS TO THE EDITOR}

death and THAT uncertainty of recovery. I asked for a lifeline from my UP Med ' 76 classmates. (The lifeline in the family was unconditionally given though from a distance). My pulmonologist classmate closely monitored my condition daily. Some offered their listening ears to my echoing worries. Most prayed to God with their unconditional love for me to recover. Another classmate had extraordinary pranic sessions for my healing, my relaxation and my energy.

I reflected on my dad's advice that in a righteous fight (like against this pneumonia), "you use all means and all ways to win."I started deep breathing into the nose and slowly out through the mouth knowing full well that the nitric oxide l absorbed through the roof of the nose dilated my coronaries for better heart function and my pulmonary arteries for better oxygen exchange. The deep breathing provided nitric oxide to the bronchus and bronchioles to dilate them for more airflow. Moreover, I was taking in lots of calamansi juices (or lemon or oranges) for its citrulline which has been researched to prolong the effects of nitric oxide. ${ }^{13}$ These breathing sessions were the MOST IMPORTANT activities if I were to survive and were continuous morning, noon and evening.

Fortunately, I was isolated in $3^{\text {rd }}$ floor Music Room with access to the roof deck garden and fresh air from Laguna de Bay (about $1.5 \mathrm{~km}$ from the house in Taguig) and of course, LPs of the Beatles, Aiza and Sharon, and Mozart. I did chest thumping or percussion as far as I could reach my back to loosen the phlegm in my lungs. This self 'physical therapy' was $3 x$ a day. I started to spit scanty whitish, thick phlegm.

I made sure that Oseltamivir (Tamiflu) was taken mornings and evenings and the Azithromycin was taken at lunch so there were no drug interactions. The 2 Colostrum tabs were swallowed on waking up. The probiotics were taken after breakfast and after dinner. The Zinc was taken after lunch. Soft stools were present but that was my GIT reacting to the medications.

Adding to the controversy was the new regimen US President Donald Trump was trumpeting on Fox News and CNN. A hospitalist physician treating COVID-19 pneumonias in San Francisco was giving us the new protocols for Chloroquine and Azithromycin, with promising results. He was the classmate of my daughter in UP Med. I went to pharmacies in Taguig and Greenhills for Chloroquine. It was not available. My pulmonologist classmate was firm; "No!" when I suggested the shift. "You will need confinement and an ECG because

\footnotetext{
REFERENCES

1. Montrose DC Floch MH. Probiotics used in human studies. J Clin Gastroenterol. 2005 Jul:39(6):469-84. DOI: 10.1097/01.mcg.0000165649.32371.71. PMID:15942432.

2. Corthésy B, Gaskins HR, Mercenier A. Cross-talk between probiotic bacteria and the host immune system. J Nutr. 2007 Mar;137(3 Suppl 2):781S-90S. DOl:10.1093/jn/137.3.781S PMID:17311975.

3. Link-Amster H, Rochat F, Saudan KY, Mignot O, Aeschlimannn JM. Modulation of a specific humoral immune response and changes in intestinal flora mediated through fermented milk intake. FEMS Immunol Med Microbiol. 1994 Nov;10(1):55-63. DOl: 10.1111/j.1574-695X.1994. tb00011.x. PubMed PMID: 7874079.

4. Trenev N. Probiotics: Nature's Internal Healers. New York: Avery (Penguin Putnam Inc.); 1998. p. 1-17.

5. Gordon S. Elie Metchnikoff: father of natural immunity. Eur JImmunol. 2008 Dec;38(12):3257-64. DOI: 10.1002/eji.200838855. PubMed PMID: 19039772.

6. O'Connor S (editor). The Science of Epidemics: Inside the fight against deadly diseases, from Ebola to AIDS. 2014, New York: Time Books; 2014. pp. 46-59.

7. Worldometer [website]. Coronavirus: Reported Cases and Deaths by Country, Territory, of Conveyance. [cited 2020 May 10] Available from: https://www.worldometers.info/
} coronavirus/\#countries these combination drugs prolong QTc on electrocardiogram." This meant Chloroquine and Azithromycin combination may initially precipitate bradycardia (lower heart rate) then ventricular tachycardia (heightened heart rate), and finally, cardiac arrest for senior patients (68 years old) like me with a history of hypertension. This discussion stopped all controversies in treatment.

Moreover, I was getting better. My temperature decreased to 37.8 ${ }^{\circ} \mathrm{C}$. The muscle pain diminished. The severe point tenderness over the lower ribs persisted. I was deep-breathing which I could not hold for more than 10 seconds. That was not normal! I listened to my lungs for the CRACKLING sounds of pneumonia with my stethoscope. The maze of gurgling and churning sounds from the stomach and intestines seemed to mask the sounds I was listening for. Or was I in denial?

I decided to go back to ER on the $3^{\text {rd }}$ day for a chest $X$ ray. The objective was to see if my pneumonia was progressing. The chest $X$ ray still showed basal pneumonia. I had mixed feelings-- good that pneumonia did not progress to middle lung fields and --- bad that pneumonia was festering.

I completed the 5-day regimen of Oseltamivir (Tamiflu) and was continuing the $8^{\text {th }}$ day of Azithromycin and N-Acetylcysteine when my COVID test finally arrived through email-- I was COVID positive \#1906.

By this time, I was recovering physically and mentally. I had no fever $\left(37.2{ }^{\circ} \mathrm{C}\right.$ average), no cough, no sore throat. Breathing was full. I had my appetite back. My outlook was as OPTIMISTIC as the blooming flowers I nurtured during this trial. This timing was fortunate because even with confirmed COVID-19 positive, I knew I had beaten COVID-19 pneumonia at home.

Isolation was completed 2 weeks from my recovery which necessitated another COVID test and rapid test April 10, 2020. This test was still positive. A third PCR done on April 20 was negative for SARSCoV-2. The new DOH protocol was to isolate up to May 5 which I have followed. I am practicing social distancing and wearing a mask.

Yours truly,

Jaime F. Flor, MD

Consultant Otorhinolaryngologist - Head and Neck Surgeon

Cardinal Santos Medical Center

Greenhills, San Juan City, Philippines

8. Rutherfurd-Markwick KJ Gill HS. Probiotics and Immunomodulation. In: Hughes DA, Darlington $L G$, Bendich A, (editors). Diet and Human Immune Function. Totowa, New Jersey: Humana Press, 2004. pp. 327-344.

9. LeBlanc JG, Laino JE, Juarez del Valle M, Vannini V, van Sinderen D, Taranto MP, et al. B-group vitamin production by lactic acid bacteria- current knowledge and potential applications. Applied Microbiology. 2011 Sep 20;111(6):1297-1309. DOI: 10.1111/j.1365-2672.2011.05157.x.

10. Bogden JD, Oleske JM, Munves EM, Lavenhar MA, Bruening KS, Kemp FW, et al.. Zinc and immunocompetence in the elderly: baseline data on zinc nutriture and immunity in unsupplemented subjects. Am J Clin Nutr. 1987 Jul;46(1):101-109. DOl:10.1093/ajcn/46.1.101. PMID:3604960.

11. Klaus-Helge I, Rink L. Zinc. In: Hughes DA, Darlington LG, Bendich A, (editors). Diet and Human Immune Function. Totowa, New Jersey: Humana Press; 2004. pp 241-259.

12. Hurley WL, Thiel PK. Perspectives on Immunoglobulins in Colostrum and Milk. Nutrients 2011 Apr;3(4):442-474. DOI: 10.3390/nu3040442. PubMed PMID: 22254105; PubMed Central PMCID: PMC3257684

13. Liuking YC, Engelen MP, Deutz NE. Regulation of nitric oxide production in health and disease Curr Opin Clin Nutr Metab Care. 2010 Jan;13(1):97-104.DOI: 10.1097/MCO.0b013e328332f99d. PubMed PMID: 19841582; PubMed Central PMCID: PMC2953417. 